\title{
A Rapid Assessment Technique to Assist Management of the White Shark (Carcharodon Carcharias) Cage Dive Industry, South Australia
}

\author{
Russell Bradford ${ }^{\mathrm{a}, *}$ and Rachel Robbins ${ }^{\mathrm{b}}$ \\ ${ }^{a}$ CSIRO Wealth from Oceans Flagship, Marine and Atmospheric Research. GPO Box 1538, Hobart, Tasmania, Austra- \\ lia 7001 \\ ${ }^{b}$ Fox Shark Research Foundation. 73 Ninth Avenue, Joslin, South Australia, Australia 5070
}

\begin{abstract}
Port Lincoln, South Australia is the departure port for the only white shark, Carcharodon carcharias, cage dive industry in Australia. Established in the early 1960's as a niche tourism venture, the industry has recently undergone a rapid expansion to accommodate greater passenger numbers, more tourism operators, and additional infrastructure aimed at capturing a greater proportion of the tourist dollar. However, to date, there has been no assessment of growth in the industry. We have used the operator logbook system, introduced in 2000, as the basis for a rapid assessment of the maturity as well as a conservative estimate of the economic value of the industry, with a focus on 2011 . From the logbook system the number of days on-site has increased from an average of 67 days per year prior to 2007 to 287 days on-site in 2011. In 2011 the industry accommodated approximately 5200 passengers with a direct domestic expenditure estimated to be in excess of 6 million AUD. Changes in shark behaviour have been observed following the increase in days on-site. The white shark cage dive industry has reached a stage in its development where increased management is required in order to ensure a viable industry into the future. The rapid assessment technique described herein will allow managers to track changes in cage dive participation rates and quickly respond to changes in the industry.
\end{abstract}

Keywords: Cage dive, Carcharodon carcharias, economic assessment, management, white shark

\section{INTRODUCTION}

Duffus and Deardon [1] define non-consumptive wildlife tourism (hereafter, wildlife tourism) to be a human recreational engagement with wildlife that does not purposefully remove the organism from its natural environment, nor permanently affect the organism as a result of the engagement. Wildlife tourism has been a rapidly expanding sector in many regions of the world and an economic value has been estimated for many wildlife tourism ventures. For example in Ghana tourism has increased $22 \%$ year-on-year since 2005 , contributing approximately $6.7 \%$ to Ghana's GDP [2]. Furthermore in the 10 years preceding 2008, the global expenditure on whale watching more than doubled to 2.1 billion USD derived from more than 13 million participants [3]. The economic value of wildlife tourism based on shark viewing is increasingly seen as an alternative to extractive uses such as fishing [4]. Participants in whale shark tourism at Ningaloo Reef, Western Australia during the peak viewing season have doubled since the late 1990s [5]. At that time the annual value of whale shark tourism was estimated at 4.7 million AUD [6]. The economic benefit to the local community of the Maldives from shark diving was estimated at 2.3 million USD in 1993 [7, 8], while in 2007 the annual

*Address correspondence to this author at the CSIRO Wealth from Oceans Flagship, Marine and Atmospheric Research. GPO Box 1538, Hobart, Tasmania, Australia 7001; Tel: (+61 3) 6232 5077; Fax: (+61 3) 6232 5000; E-mail: Russ.Bradford@csiro.au revenue from shark diving in the Bahamas was estimated at 78 million USD [9]. Shark diving in Palau, Micronesia has been valued at 18 million USD, accounting for about $8 \%$ of GDP $[10,11]$.

Wildlife tourism is predicted to result in changes to the user-base, the target species, and the environment; which in turn have considerable management implications [1]. The challenge for researchers and managers alike will be to determine the metric, or series of metrics, that can be used to monitor these changes in wildlife tourism ventures. Although analyses of expenditure only address relatively simple components of value, such as regional economic impact [1], they can be used as a rapid assessment method to form the basis for a more detailed examination of the economic and social impacts of wildlife tourism and alert managers to changes that occur over time.

Successful wildlife tourism ventures are generally based upon a species that provokes a high degree of stimulation such as the great predators (e.g. lions, tigers, sharks) [1, 12], and they typically require a predictable occurrence of the target species within a fairly confined spatial area, often coincident with a special life history requirement of the species [1]. The white shark (Carcharodon carcharias) fulfils these requirements and forms the basis of shark cage diving experiences in Australia, South Africa, New Zealand, the USA, and Mexico $[13,14]$. In Australia the white shark cage diving experience is only available in South Australia at the Neptune Islands which support the largest aggregations of pinnipeds in Australian waters [15], made up of breeding 
colonies of New Zealand fur seals (Arctocepalus forsteri) and a haul out zone for Australian sea-lions (Neophoca cinerea). Although predation events on pinnipeds are only occasionally observed at the Neptune Islands (A. Fox, pers comm.), white sharks are believed to visit this site to provision on pinnipeds; thus the islands serve to seasonally concentrate their localised spatial distribution which in turn facilitates the viewing opportunities of tourists.

A recent study on the impact of cage diving on the behaviour of white sharks at the Neptune Islands has demonstrated an impact on the target species that may be due to an increase in the level of exposure to tourism operations [16, 17]. For example, increases were observed in shark sightings and the average period of residency following an increase in cage diving activity at the Neptune Islands $[16,17]$. In addition, there were changes in diel activity patterns at the cage diving site that were not observed at a site in close proximity that is rarely utilised by the shark cage dive operators [16, 17]. From its inception in the mid 1970's until 2007, the shark cage dive industry in South Australia consisted of two operators providing infrequent multi-day expeditions to view the sharks. However, 2007 saw a shift by one operator towards a highly regular single-day expedition model. A third operator, providing single-day expeditions, began operations partway through 2011. These changes to the industry have resulted in a four-fold increase in the number of days where cage dive operations occur at the Neptune Islands.

To date there has been no assessment of the growth or economic importance of the white shark cage diving industry in South Australia. The aim of this paper is to present a rapid assessment of the maturity of the shark cage dive industry operating out of Port Lincoln, South Australia. The assessment is based on data readily available through the operator logbook system introduced in 2000. By using these data, managers will be able to gain insight into the level of tourist participation and their economic motivation without having to undertake a comprehensive customer survey. By design, this assessment does not examine all economic input or output, only those values which can be easily and quickly estimated based on the operator logbook system. The rapid assessment technique should allow managers to respond in a timely fashion, through adaptive management, to changes in the user-base that may further impact the target species and its environment.

\section{METHODS}

For the following rapid assessment we have restricted our analyses to only those items of tourist expenditure of direct consequence of participating in a white shark cage dive charter. This expenditure represents a measure of motivation (i.e. the greater the expenditure, the greater the motivation) that can be easily replicated in subsequent assessments. By design we do not assess the flow-on effects such as vessel maintenance, mooring costs, employment, or tourist expenditure associated with extended stays in the region. Our aim was to provide a rapid assessment of a readily available data source that can be easily compared between years.

As part of the regulations governing white shark cage dive tourism in South Australia, shark cage dive operators (SCDO) are required to fill out a trip logbook for each day they are on-site at the Neptune Islands. Beginning in February 2011 the logbook separated the passengers by origin into international or Australian. The SCDO logbooks were examined to provide an historical perspective in the number of charters and changes in the trip lengths, as well as to provide the basis for a more detailed examination of the industry during the period of January 1, 2011 to December 31, 2011. According to the business practice of each SCD operator, passenger surveys are carried out which allowed the authors to supplement some data derived from the logbooks.

\section{ASSUMPTIONS}

A number of assumptions have been used to estimate the tourist expenditure associated with accommodation either side of the expedition dates. Due to the distance from Port Lincoln to the Neptune Islands Marine Reserve passengers on single-day charters typically depart the marina by 0700 , and return to the marina around 1800 or later. As a result, passengers are unable to fly in or out of Port Lincoln on the day of the charter; thus requiring a minimum two night's accommodation per passenger as a direct consequence of participating in a shark cage dive.

Accommodation requirements for those passengers on multiday charters are more complex to estimate. During the summer period, dive charters will depart too early and arrive back into port too late to take advantage of the same day flight into or out of Port Lincoln. These passengers will typically require two nights of accommodation within the region. During the winter period however, the embarkation and disembarkation times allow for arrival and departure on the same day. We therefore do not apply an accommodation cost to passengers on the winter multiday dive charters.

Accommodation expenditure was estimated by collating daily accommodation rates, as posted on the internet, for 11 hotels spanning the range of backpacker/hostel style rooms to single occupancy in a moderate hotel. For the purposes of this assessment we have ignored seasonal fluctuations in the cost of accommodation. However, the authors note that accommodation rates are fairly stable and display little seasonal variation.

The majority of passengers come from outside of Port Lincoln and surrounds, and would typically fly to Port Lincoln via Adelaide. A typical airfare was estimated based on an internet search of fares for the two airlines servicing Port Lincoln from Adelaide. In addition to the internal domestic flight, many passengers have an international origin and therefore incur additional travel costs. We have performed an internet search of airfares between key international hubs and Adelaide in order to provide an estimate of return airfare expenditure incurred flying to Australia.

Two operators provide a "no shark" policy resulting in a reduced expedition fee for a subsequent expedition, while the third operator (Operator $\mathrm{C}$ ) provides an additional cost to enter the surface cage only if a shark is present.

The "no shark" policy of Operator A provides for a halfprice expedition valid for 12 months from date of issue. Passengers who invoke the half price "no shark" voucher would typically incur additional expenditure related to an additional night's accommodation, meals and transfers between the city 


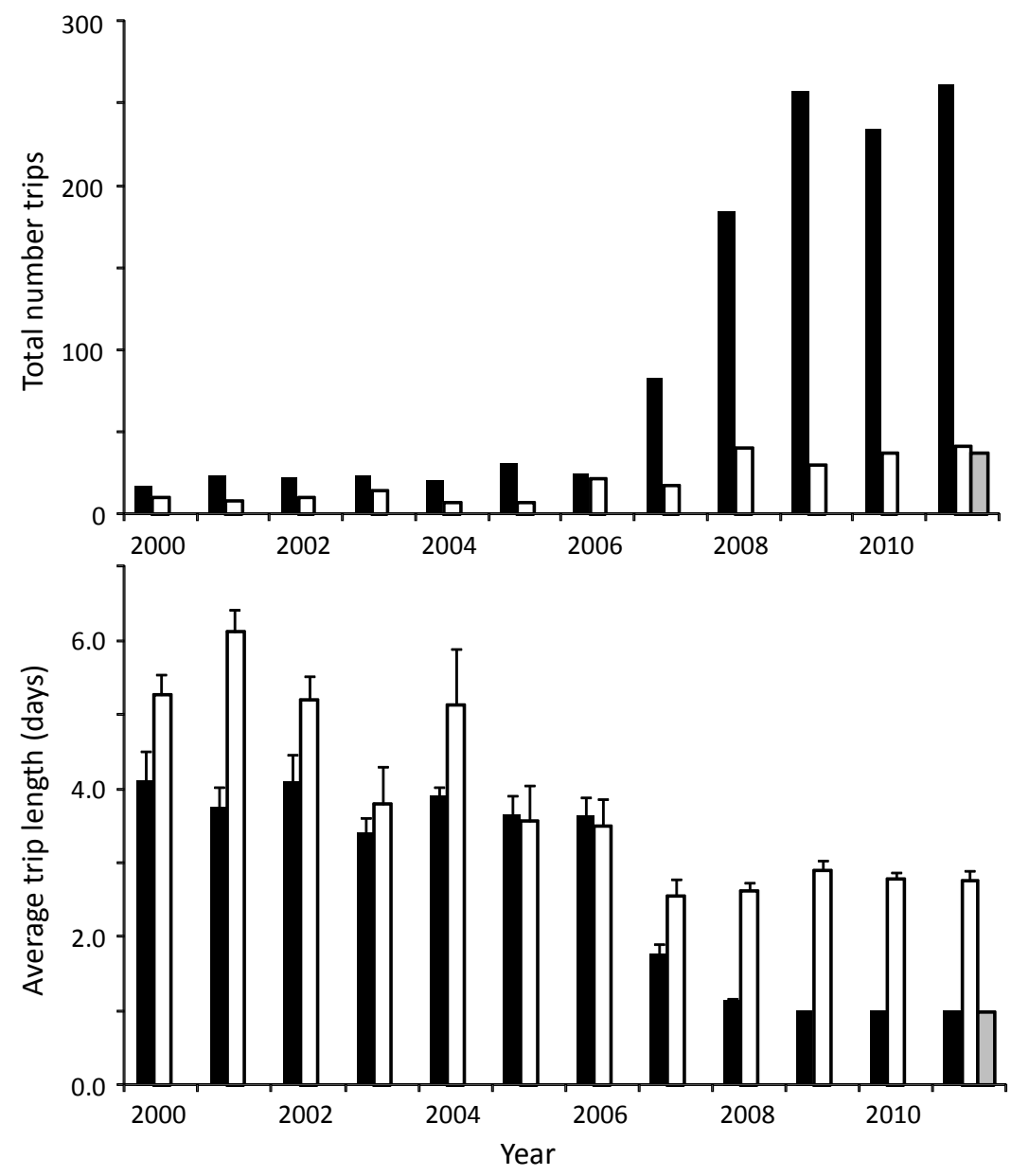

Fig. (1). Historical trends in the Port Lincoln, South Australia, shark cage dive industry. A: total number of trips by operator by year. B: Average trip length (days) by operator by year. Closed bars = operator A, open bars = operator B, grey bars $=$ operator C referred to in the text.

and the marina from which the tour departs. Affected passengers would also alter the calculation of airfares between Adelaide and Port Lincoln by reducing the total number of flights by the number of passengers affected. In calculating the total passenger expenditure for operator A we have used both the values assuming no passenger invoked the half price voucher, and assuming every affected passenger invoked the half price voucher for the following day.

The "no shark" policy of Operator B provides for a halfprice charter valid for 30 months. In addition, if no sharks are sighted on the expedition on which the "no shark" voucher is activated, the passenger is able to access a third expedition at no cost. To account for this policy the operator has provided information on the number of passengers who have invoked the voucher. It is assumed that these passengers still incur all other costs associated with travel to participate in an expedition.

For convenience the economic components derived from passenger numbers reported in the logbook system have been divided into three categories: domestic impact, representing tourist expenditure in the regional economy (e.g. accommodation, meals, transfers, and domestic flights); international impact, representing tourist expenditure on international flights that does not necessarily benefit the regional economy; output, representing direct tourist expenditure to participate in a cage dive (e.g. charter fees).

\section{RESULTS}

\section{Historical Trend in Expedition Numbers and Trip Length}

Prior to 2007 SCDO expeditions were infrequent, averaging fewer than 25 trips per annum by either operator; each trip almost always extended over multiple days. However, in 2007 there was a transitional change in business model by one operator that resulted in a dramatic increase in the number of charters per annum (Fig. 1A) with a concomitant reduction in trip duration to favour single-day charters (Fig. 1B). From 2008 onwards the number of single-day charters increased to an average of $\sim 250$ per annum, with a slight increase in multiday trips to average about 30 per annum. In April 2011 a third operator entered the industry offering single-day charters.

\section{Focus: 2011 Financial Year}

During the period January 1, 2011-December 31, 2011 there was a total of 5,241 passengers who took part in a total of 301 shark cage dive expeditions. Of these 2,765 were Australia-based, 1,549 originated from an international port, and a further 917 were from an unspecified origin. The majority of passengers, 4,861, opted for one of the single-day shark cage dive expeditions. Combining the three economic 
Table 1. Domestic Impact, Representing Tourist Travel Expenditure on items Associated with Participating in white Shark Cage Dive Charter

\begin{tabular}{|c|c|c|}
\hline Component & Unit Cost (Estimate) & Total Expenditure (Estimate 2011) \\
\hline \hline Airfare (return) & 280.00 & $1,464,680.00$ \\
\hline Accommodation & 98.00 & $969,514.00$ \\
\hline Meals & 50.00 & $508,300.00$ \\
\hline Transfers & 50.00 & $214,790.00$ \\
\hline
\end{tabular}

Table 2. Conservative Airfares between key International Hubs and Adelaide, South Australia Derived from a Search of Web Fares Available between August and September. The Average International Airfare was Used for travelLers from International Destinations Making up Less than 1\% of Charter Passengers or where International Origin was Unknown

\begin{tabular}{|c|c|}
\hline International Hub & Estimated return Airfare (AUD) \\
\hline \hline London, UK & $1,800.00$ \\
\hline Los Angeles, USA & $1,400.00$ \\
\hline Vancouver, Canada & $1,800.00$ \\
\hline Tokyo, Japan & $1,900.00$ \\
\hline Auckland, New Zealand & 600.00 \\
\hline Average international airfare (excluding NZ) & $1,700.00$ \\
\hline
\end{tabular}

Table 3. Representative Charter Fees (2011) for Shark Cage Diving at the Neptune Islands, South Australia

\begin{tabular}{|c|c|c|c|c|}
\hline & \multicolumn{2}{|c|}{ Basic Fee (AUD) } & Extras (AUD) & Cage (AUD) \\
\hline & Adult & Child & 50.00 & inclusive \\
\hline \hline Operator A & $495.00 / 395.00^{\mathrm{a}}$ & $247.20 / 197.50^{\mathrm{a}}$ & & inclusive \\
\hline Operator B & $572.00^{\mathrm{b}}$ & 572.00 & & 100.00 \\
\hline Operator C & 295.00 & 195.00 & & \\
\hline
\end{tabular}

${ }^{\mathrm{a}}$ Discount applied to spectator only passenger.

${ }^{\mathrm{b}}$ Average daily fee, actual fee varies depending on length of trip.

components, total expenditure was estimated at 9,131,604 AUD.

\section{Domestic Impact}

Based on the number of passengers participating in a white shark cage dive charter during 2011, the total domestic impact was estimated at 3,157,284.00 AUD $(34.6 \%$ of the three economic components). Domestic airfares accounted for $46.4 \%$, accommodation $30.7 \%$, meals $16.1 \%$, and transfers $6.8 \%$ of the total domestic impact (Table 1).

\section{International Impact}

International impact is the amount of expenditure estimated to have been spent on international airfares to participate in a white shark cage dive charter. One operator provided a comprehensive breakdown of the international origin of passengers, and these data have been used to provide an average international airfare where passenger origin was not available (Table 2). Based on the number of international passengers participating in a cage dive charter during 2011, the total international impact was estimated at 2,624,400.00 AUD (28.7\% of the three economic components).

\section{Output}

Charter fees vary by operator; representative fees are presented in Table 3. Output, or expenditure on charter fees to participate in a white shark cage dive, totalled 3,349,920.00 AUD in 2011 (36.7\% of the three economic components). For operator B during 2011 no passengers redeemed a "no shark" voucher. Assuming full uptake of the "no shark" policy provided by operator A only marginally reduced output by 18,900 AUD. We have not included expenditure on "extras" packages such as a souvenir DVD or wet suit hire in the calculation of output because these data are not recorded in the operator logbook system and, therefore, not readily available.

\section{DISCUSSION}

The data presented in this paper do not attempt to cover the full spectrum of economic impact derived from the white shark cage dive industry. The aim was to describe a technique to rapidly assess the maturity of the industry and provide an economic measure that could easily be replicated in subsequent analyses to provide a relative metric of direct comparison between analyses. 
The Neptune Islands are an important focal point for white sharks within their Australian distribution. The islands support the largest aggregation of pinnipeds in Australia [15, 18], and the long-term shark cage dive operators have documented the regular return of individual white sharks over several years as well as recruitment of individuals new to the operators [19]. The reliable occurrence of white sharks at this site supports the only white shark cage dive tourism operation in Australian waters.

Conceived in the early 1960's the white shark cage dive industry remained largely within the domain of a specialised market until the 2000's. The introduction of berley and park access permits along with operator trip logbooks in the early 2000 's heralded the beginning of greater regulation within the industry and a broader client base. In 2007, day trips were introduced to the industry opening the way for a more generalist-orientated market. Tourist numbers steadily increased until 2009 by which time tourist numbers began to stabilise. The development of the industry appears to be closely reminiscent of the lifecycle framework introduced by Duffus and Deardon [1].

Implicit within the lifecycle framework is the understanding that the level of environmental impact due to tourism will change over time. Indeed a recent study $[16,17]$ found that the white shark cage dive operations at the Neptune Islands have produced quantifiable changes in the distribution and behaviour of the white sharks visiting North Neptune Island (the primary site for dive expeditions). Inherent in this finding, a risk exists to the white shark population at the Neptune Islands from increased wildlife tourism. However, until now there has been no analysis of the development of the industry, and no metric to compare development through time.

The year 2011 represents the current stable reference level for shark cage dive tourist numbers. In that year more than 5200 tourists participated in at least one of the 301 shark cage dive charters registered in that year. Australianbased tourists accounted for at least $53 \%$ of passengers; international-based tourists accounted for at least $30 \%$ of passengers; with the origin of the remaining passengers not being specified. Conservatively these tourists injected approximately 6.5 million AUD into the local and South Australian state economies as a direct result of the shark cage dive industry, with international tourists spending an additional 2.6 million AUD on international airfares. Although each of the SCD operators have indicated that the primary reason of their passenger's trip was to participate in a shark cage dive, further research, including a comprehensive passenger survey, would assist with refining the domestic impact to the regional economy derived from adjunct tours and extended stays within the region.

The rapid assessment technique presented herein provides managers with a mechanism to monitor growth (or decline) in the white shark cage dive industry using the operator logbook system. The level of tourist participation in white shark cage diving is easily determined; these data also provide the basis for estimating the economic motivation of tourists that is comparable between years without resorting to lengthy customer surveys. Coupled with research into changes in the distribution and behaviour of the white sharks, managers should be able to respond, through adaptive management, to ensure the industry remains viable and reduce adverse impacts on the white shark and its environment.

\section{CONFLICT OF INTEREST}

The authors confirm that this article content has no conflicts of interest.

\section{ACKNOWLEDGEMENTS}

The authors would like to thank the shark cage dive industry of Port Lincoln, South Australia for their cooperation and support, specifically, Calypso Star Charters, Rodney Fox Shark Expeditions and Adventure Bay Charters. The manuscript greatly benefited from comments supplied by Dr Fabio Boschetti and Dr Lucy Robinson, and two anonymous reviewers. The development of this manuscript was funded by the CSIRO Wealth from Oceans.

\section{REFERENCES}

[1] Duffus DA, Deardon P. Non-consumptive wildlife-orientated recreation: a conceptual framework. Biol Conserv 1990; 53: 213-31.

[2] Jachmann H, Blanc J, Nateg C, et al. Protected area performance and tourism in Ghana. S Afr J Wildl Res 2011; 41: 95-109.

[3] O'Connor S, Campbell R, Cortez H, Knowles T. Whale Watching Worldwide: tourism numbers, expenditures and expanding economic benefits: a special report. IFAW 2009: Yarmouth MA, USA. prepared by Economists at Large.

[4] Clua E, Buray N, Legendre P, Mourier J, Planes S. Business partner or simple catch? the economic value of the sicklefin lemon shark in French Polynesia. Mar Freshw Res 2011; 62: 764-70.

[5] Catlin J, Jones R. Whale shark tourism at Ningaloo Marine Park: a longitudinal study of wildlife tourism. Tour Manage 2010; 31: 38694.

[6] Davis D, Banks S, Birtles A, Valantine P, Cuthill M. Whale sharks in Ningaloo Marine Park: managing tourism in an Australian marine protected area. Tour Manage 1997; 18: 259-71.

[7] Anderson RC, Ahmed H. The shark fisheries of the Maldives: a review report. Republic of Maldives and Food and Agriculture Organization of the United Nations. Ministry of Fisheries and Agriculture 1993: p.76

[8] Anderson RC, Waheed A. The economics of shark and ray watching in the Maldives. Shark News 2001; 13: 1-3.

[9] Cline W. Shark diving overview for the islands of the Bahamas. Nassau, report of the Bahamas. Nassau, Bahamas: Cline Marketing Group. Minis Tour 2008: p. 11.

[10] Vianna GMS, Meekan MG, Pannell DJ, Marsh SP, Meeuwig JJ. Socio-economic value and community benefits from shark-diving tourism in Palau: a sustainable use of reef shark populations. Biol Conserv 2012; 145: 267-77.

[11] Vianna GM, Meekan MG, Pannell D, Marsh S, Meeuwig JJ. Wanted dead or alive? the relative value of reef sharks as a fishery and an ecotourism asset in Palau, Perth. Australian Institute of Marine Science and University of Western Australia, Perth 2010; p. 34.

[12] Gallagher AJ, Hammerschlag N. Global shark currency: the distribution, frequency, and economic value of shark ecotourism. Curr Issue Tour 2011; 14: 797-812.

[13] Malcolm H, Bruce BD, Stevens JD. A review of the biology and status of white sharks in Australian waters: report to environment Australia, marine species protection program. CSIRO Research 2001, Hobart; p. 81.

[14] Laroche RK, Kock AA, Dill LM, Oosthuizen WH. Effects of provisioning ecotourism activity on the behaviour of white sharks, Carcharodon carcharias. Mar Ecol Prog Ser 2007; 338: 199-209.

[15] Shaughnessy PD, McKeown A. Trends in abundance of New Zealand fur seals, Arctocephalus forsteri, at the Neptune Islands, South Australia. Wildl Res 2002; 29: 363-70. 
[16] Bruce B, Bradford R. The effects of burleying on the distribution and behaviour of white sharks, Carcharodon carcharias, at the Neptune Islands, South Australia: final report. Department of Environment and Natural Resources, South Australia 2011.

[17] Bruce B, Bradford R. The effects of shark-cage diving operations on the behavior and movements of white sharks, Carcharodon carcharias, at the Neptune Islands, South Australia. Mar Biol 2013; DOI: $10.1007 / \mathrm{s} 00227-012-2142-\mathrm{z}$.
[18] Robinson AC, Canty PD, Mooney PA, Ruddock PM. South Australia's Offshore Islands. Adelaide, Australia. Department of Environment and Natural Resources, South Australia 1996.

[19] Robbins RL, Booth DJ. Seasonal sexual and size segregation of white sharks, Carcharodon carcharias, at the Neptune Islands, South Australia. In: Domeier ML, Ed. Global perspectives on the biology and life history of the white shark. Boca Raton, Fl: CRC Press 2012, pp. 287-99.

(C) Bradford and Robbins; Licensee Bentham Open.

This is an open access article licensed under the terms of the Creative Commons Attribution Non-Commercial License (http://creativecommons.org/licenses/ by-nc/3.0/) which permits unrestricted, non-commercial use, distribution and reproduction in any medium, provided the work is properly cited. 